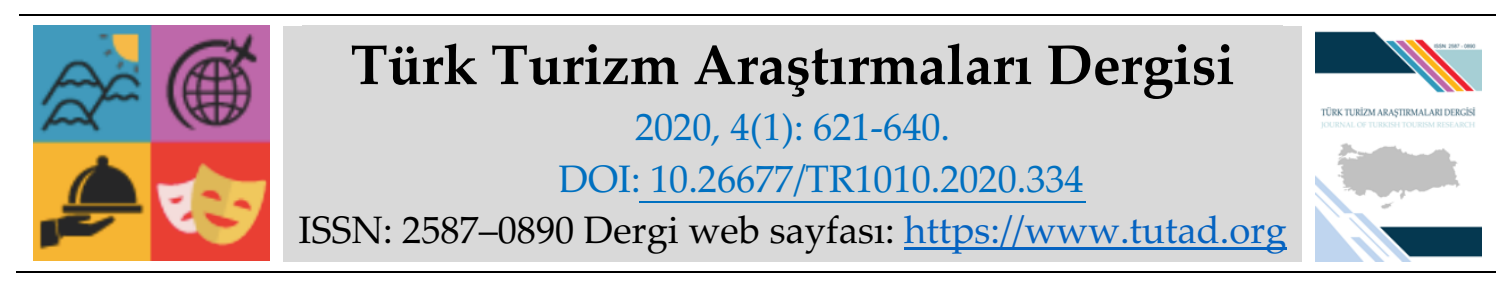

ARASTTIRMA MAKALESI

\title{
Rekreatif Amaçlı Seyahat Eden Motosiklet Kullanıcılarının Sosyal Kimlikleri Üzerine Bir Ölçek Geliştirme Çalışması
}

Arş. Gör. Dr. Mehmet ERTAŞ, Pamukkale Üniversitesi, Turizm Fakültesi, Denizli, e-posta: mehmetertas@pau.edu.tr

ORCID: https://orcid.org/0000-0003-4396-5104

Öz

İnsanlar hayatları boyunca birçok gruba girmekte ve üye olmaktadır. Gönüllü olarak üye olunan bu gruplar kişinin sosyal kimliğini etkileyerek yeni bir sosyal kimliğin ortaya çımasını sağlamaktadır. Bu çalışmanın amacı ise serbest zamanlarında motosiklet ile seyahat eden ve bir motosiklet grubuna üye olan motosiklet kullanıcılarının sosyal kimliklerini ortaya çıkarmaktır. Aynı zamanda bu çalışmada motosiklet kullanıcılarına özgü sosyal kimlik ölçeğinin geliştirilmesi amaçlanmaktadır. Araştırmada nitel ve nicel yöntemler kullanılarak dört aşamada veri toplanmıştır. Nitel yöntemler olarak 27 kişi ile yarı yapılandırılmış soru formu, 33 kişi ile tam yapılandırılmış soru formu ile mülakatlar yapılmış ve üç adet odak grup çalışması gerçekleştirilmiştir. Daha sonra 486 adet anket toplanmış ve açıklayıcı faktör analizi yapılmıştır. Araştırmanın sonucunda, motosiklet gruplarına üye olan bireylerin sosyal kimlik belirleyicilerinin duygusal bağ, güvenlik, özgürlük hissi ve motosiklet ile seyahat etme ve gruba üye olması sonuncunda elde ettiği kazanımlar olarak ortaya çıkmıştır.

Anahtar Kelimeler: Rekreasyon, Sosyal Kimlik, Motosiklet, Gruplar, Ölçek Geliştirme.

Makale Gönderme Tarihi: 25.10.2019

Makale Kabul Tarihi: 07.01.2020

\section{Önerilen Atıf:}

Ertaş, M. (2020). Rekreatif Amaçlı Seyahat Eden Motosiklet Kullanıcılarının Sosyal Kimlikleri Üzerine Bir Ölçek Geliştirme Çalışması, Türk Turizm Araştırmaları Dergisi, 4(1): 621-640.

(C) 2020 Türk Turizm Araştırmaları Dergisi. 


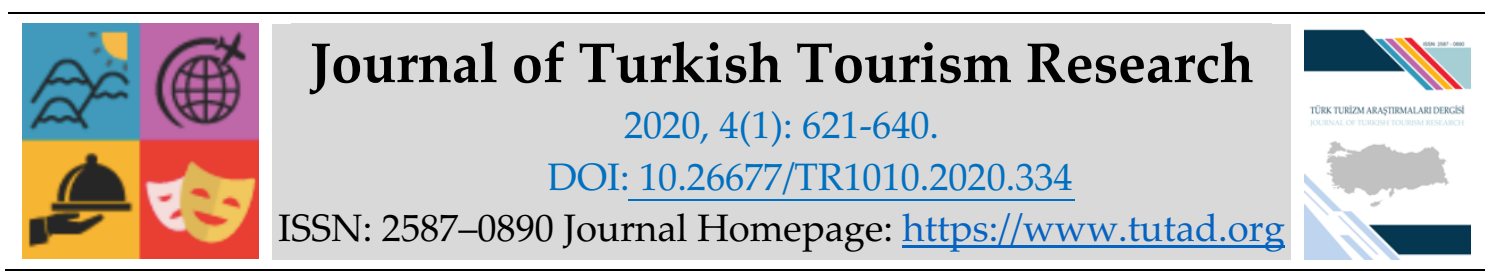

\title{
RESEARCH PAPER
}

\section{A Scale Development Study on the Social Identity of Motorcycle Users Traveling for Recreational Purposes}

Dr. Mehmet ERTAŞ, Pamukkale University, Faculty of Tourism, Denizli, e-mail: mehmetertas@pau.edu.tr

ORCID: https://orcid.org/0000-0003-4396-5104

\begin{abstract}
People are members of many groups throughout their lives. These groups, in which people voluntarily become members, affect the social identity of the person and enable the emergence of a new social identity. The purpose of this study is to reveal the social identity of a motorcycle user who the members of motorcycle groups and travel with a motorcycle in their leisure time. Also, the aim of this study is to develop a social identity scale of motorcycle users. Data were collected in four stages using both qualitative and quantitative research methods. As qualitative methods, 27 motorcycle users were interviewed with semi-structured questionnaires, 33 motorcycle users were interviewed with structured questionnaires and three focus group studies were conducted. Then, 486 questionnaires were collected and explanatory factor analysis was conducted. Results conclude that the social identity determinants of motorcycle users have emerged a strong emotional bond, feelings of safety, freedom, travelling by motorcycle and membership of the group.
\end{abstract}

Keywords: Recreation, Social Identity, Motorcycle, Groups, Scale Development.

Received: 25.10.2019

Accepted: 07.01.2020

\section{Suggested Citation:}

Ertaş, M. (2020). A Scale Development Study on the Social Identity of Motorcycle Users Traveling for Recreational Purposes, Journal of Turkish Tourism Research, 4(1): 621-640.

(C) 2020 Türk Turizm Araştırmaları Dergisi. 


\section{Gíriş}

Sosyal kimlik kuramı sosyal psikoloji içerisinde grup üyeliği, grup oluşma süreci ve gruplar arasındaki ilişkiyi konu alan önemli bir kavramdır. Sosyal kimlik kuramı ilk olarak Muzaffer Sherif' in (1967) yapmış olduğu grup içi ve gruplar arası etkileşimleri gözlemleme çalışmalarıyla başlamıştır. Daha sonra 1980'li yıllarda Tajfel (1978), Tajfel ve Turner, (1979) ve Turner (1982) tarafından sosyal kimlik teorisi başlığı altında çalışılmaya devam edilmiştir. Grup yapısı ve dinamikleri hem sosyal psikolojinin hem de sosyolojinin konusu olmasıyla birlikte bu çalışmada sosyal psikoloji içerisinde yer alan sosyal kimlik kuramı açısından açıklanmaya çalışılacaktır.

Sosyal kimlik kuramına göre kişi kendisini grup üyelikleri açısından tanımlamaktadır. Bu tanımlama, bir gruba olan aidiyet algısıdır ve başarıların ve başarısızlıkların doğrudan veya dolaylı deneyimini içermektedir (Ashforth ve Mael, 1989; Green ve Jones, 2005; Cruwys, Haslam, Dingle, Haslam ve Jetten, 2014). Aynı zamanda sosyal kimlik kuramı, başlangıcından bu yana, insanların ne zaman ve neden düşünebildiğini, hissettiğini, insanların kendilerini daha geniş bir sosyal yapıya nasıl bağladıklarını tahmin etmeye yardımcı olan temel bilişsel süreçleri ve sosyal koşulları içermektedir (Hogg ve Abrams, 1998; Haslam, Jetten, Postmes ve Haslam, 2009; Swann ve Bosson, 2010; Ellemers, 2012). Diğer taraftan sosyal kimlik kuramının temelinde insanların, grup üyelikleri açısından davranış eğilimlerini belirleyen, belirli bir sosyal grupla özdeşleşmesi yer almaktadır. Bu anlamda sosyal kimlik, öncelikle, farklı sosyal kategori (bilişsel bileşen) üyeleri arasında ayrım yapma olasılığından ziyade, gruba duyuşsal bağlılık hissini (duygusal bileşen) ifade etmek için kullanılır. Bu nedenle bireyin grup üyeliğine olan bilişsel farkındalığını (değerlendirici bileşen), söz konusu gruba duygusal olarak hissettiği bağlllık düzeyinden (duygusal bağlılık) ayırt etmenin önemli olduğu düşünülmektedir (Ellemers, Kortekaas ve Ouwerkerk, 1999).

Araştırmacılar sosyal kimliğin üç temel boyutu üzerine odaklanmaktadır (Tajfel, 1981; Jones, 2000; Deaux, 2002). Bunlar: bilişsel (grup üyeliği bilgisi, farkındalığı ve kendini sınıflandırma) duygusal (grup üyeliğinin önemi, etkisi ve bağlllı̆̆1) ve değerlendirici (grup üyeliğine verilen değer, üyelerin birbirine ve gruba bağlllığı) özelliklerdir. Bilişsel yön, bireyleri tanımlamak için kullanılan grupların ve onların diğer gruplarla ilişkilerinin içsel temsilidir (Hogg ve Williams, 2000). Bununla birlikte bilişsel yön, insanların kendilerini belirli bir grubun üyesi olarak sinıflandırması veya gruba ait bilgisi anlamına gelmektedir (Tajfel, 1978; Tajfel, 1981). Duygusal yön, gruba duyulan bağlllı̆ga odaklanır ve bağlllık nispeten yüksek bir statüye sahip olunduğunda ortaya çıkar (Ellemers vd., 1999). Aynı zamanda duygusal yön, insanların gruptaki üyelikleri hakkında sahip oldukları duyguları ifade eder ve gruba duyuşsal bağlılık duygusunu yansitır (Packer, 2008). Değerlendirici yön ise, diğer gruplarla ilişkili özelliklerin niteliğini içeren sosyal bağlam aracılığıyla ortaya çıkar (Tajfel, 1982). Ayrıca değerlendirici yön, bireyin grup tabanlı veya kolektif benlik saygısı olarak ölçülür ve topluma aidiyet temelinde öz değer olarak tanımlanır (Deaux 2002).

Literatürdeki sosyal kimlik çalışmalarına bakıldığında gruplar arası davranışlar (Tajfel ve Turner, 1979), sosyal kimlik kazanımları (Green ve Jones, 2005), sosyal kimliğin depresyonla başa çıkmada rolü (Cruwys vd., 2014) ve gruba bağlılığın sosyal kimliğe etkisi (Ashforth ve Mael, 1989; Swann ve Bosson, 2010; Ellemers, 2012; Hogg, Abrams ve Brewer, 2017) gibi konulara odaklanılmıştır. Rekreatif gruplara üye kişilerin sosyal kimlikleri üzerine yapılan çalışmalar ise sınırlıdır (Harris, 2016). Bu doğrultuda bu çalışmanın amacı, serbest zamanlarında motosiklet ile seyahat eden ve bir motosiklet grubuna üye olan kişilerin sosyal kimliklerini ortaya çıkarmaktır. Ayrıca çalışmanın diğer bir temel amacı motosiklet kullanıcılarına özgü sosyal kimlik ölçeğini geliştirmektir. 


\section{LITERATÜR TARAMASI}

\section{Sosyal Kimlik}

Sosyal kimlik, "bireylerin kendi benlik kavramlarını bir parçası olarak, sosyal bir gruba (veya gruplara) üyeliği hakkındaki bilgisi ve bu üyeliğe verilen değer ve duygusal önem ile ilişkisi" olarak tanımlanmaktadır (Tajfel, 1978: 63; Tajfel ve Turner, 1979: 40; Tajfel, 1981: 255). Bununla birlikte sosyal kimlik farklı anlamlar içerisinde kullanılmıştır. Sosyal kimlik ilk olarak, benzerliklerimizin ve başkalarıyla olan farklılıklarımızın bir fonksiyonu olarak kim olduğumuzu tanımlayan ilişkisel bir terimdir. İkincisi, sosyal kimlik başkalarıyla paylaşılır ve paylaşılan sosyal eyleme bir temel sağlar. Üçüncüsü, herhangi bir sosyal kimlikle ilişkili anlamlar, kolektif tarihimizin ve günümüzün ürünleridir. Dolayısıyla sosyal kimlik, bizi sosyal dünyaya bağlayan bir kavramdır. Sosyal kimliğin, birey ve toplum arasındaki dengeyi sağladığı söylenebilir (Reicher, Spears ve Haslam, 2010).

Bir sosyal grup, aynı sosyal kimliğe sahip iki kişiden oluşan bir koleksiyondur ve kişilerin sosyal kimliği, sahip oldukları kişisel kimlikleri ve belirli dış gruplardan nasıl farklılaştıklarıyla belirlenmektedir. Grup üyeliği, kolektif bir kendilik kurgusunun, "biz", "bize" ve "onlar" ölçeğinde değerlendirilmesi olarak kabul edilebilir. Diğer taraftan sosyal kimlik, kişisel kimlikten oldukça farklıdır. Kişisel kimlik, diğer insanlarla paylaşılmayan kendine özgü kişilik özellikleri ("ben") ve tamamen ikili ilişki ("biz" ve "siz") içindeki diğer kişiye bağlı olan yakın kişisel ilişkiler açısından bir benlik kurgusudur (Hogg, Abrams, Otten ve Hinkle, 2004). Örneğin birey, grup içindeki diğer kişilerden farklı olarak kendisini bireysel bir kişi olarak kategorize edebilir veya kendisini dış gruptan farklı bir ana grup olarak kabul edebilir (Turner, Reynolds, Haslam ve Veenstra, 2006).

Grup üyeleri aynı zamanda kendilerini sosyal kimlik açısından tanımlayacaklarından diğer grup üyelerini kendileri gibi görmeye başlamaktadır (Swann, Jetten, Gomez, Whitehouse ve Bastian, 2012). Ayrıca sosyal kimlik göze çarpan bir şekilde belirgin olduğunda, kişinin yaşamının diğer yönlerini (sosyal yükümlülükler ve aile) gölgede bırakmaktadır (Packer, 2008; Jetten, Haslam, Haslam, Dingle ve Jones, 2014; Harris, 2016). Bu nedenle sosyal kimlik, bireyin sosyal gruplara üyeliği ile o kadar sıkı sıkıya ilişkilidir ki, "ben" in "biz" den ayırt edilebilmesinde büyük güçlükle karşı karşıya kalınabilmektedir (Hogg ve Williams, 2000). Bu durum ben ve diğerleri arasındaki ilişkinin yeniden formüle edilmesini gerektirmektedir (Jetten, $\mathrm{O}^{\prime}$ Brien ve Trindall, 2002).

Sosyal kimlik kuramı orijinal olarak iki tür benlik ve kimlik arasında ayrım yapmıştır. Burada benlik, bireyi tanımlayan bir sosyal kategorinin (sosyal kimlik) diğer üyeler ile paylaşılan nitelikler açısından tanımlanması ve değerlendirilmesi olarak kabul edilmektedir (Tajfel ve Turner, 1979; Arkonaç, 2008; Hogg vd., 2017). Bu nedenle sosyal kimlik, bir bireyin grup üyeliğine (ör., "Demokrat", "Amerikan"), kişisel kimlik ise grup üyeliğinden bağımsız kişinin özelliklerine (ör., "akıllı", "sosyal”) odaklanmaktadır (Packer, 2008; Swann vd., 2012).

Sosyal kimlik kuramı, benliğin bir teorisidir (Brewer ve Gardner, 1996; Hogg ve Williams, 2000; Hogg ve Vaughan, 2007). Grup üyeliği; grup süreçleri ve gruplar arası davranış ile ilişkili olan kolektif benlik (sosyal kimlik) ile kişinin yakın kişisel ilişkileri ve özverili özellikleriyle ilişkili bireysel benlik (kişisel kimlik) arasındaki ayrımı konu almaktadır (Tajfel ve Turner, 1979). Ayrıca sosyal kimlik kuramı, birçok sosyal bağlamda insanların grup üyelikleri açısından benlik algılarını tanımladıklarını varsaymaktadır. Bu, bir kişinin psikolojisinin, genellikle kendini tanımlayan grupların durumuna bağlı olduğu anlamına gelmektedir. Eğer bu gruplar istikrar, anlam, amaç ve yön sahibi bir kimlik sağlıyorsa, bireyin ruh sağlığının olumlu etkileneceği varsayımında bulunulabilir (Haslam vd., 2009). Sosyal kimlik kuramı aynı zamanda kişilerin 
olumlu benlik saygısına erişmek ve sürdürmek arzusuyla motive olduğu önemli ve geniş kapsamlı bir öneri ortaya koymaktadır (Tajfel ve Turner, 1979; Hoyle ve Crawford, 1994; Hogg ve Abrams, 1998).

Sosyal psikolojideki sosyal kimlik perspektifi, sosyal grup ve grup üyeliğinin bilişsel ve özkavramsal tanımına dayanan büyük ölçekli sosyal kategoriler arası ilişkilerin bir analizi olarak görülür (Hogg vd., 2004). Sosyal kimlik yaklaşımı, bireylerin düşüncelerini, inançlarını ve eylemlerini anlamak için, kendilerini başkalarına göre nasıl kategorize ettiklerini anlamamız gerektiği varsayımıyla başlar. Dolayısıyla sosyal kimlik, paylaşılan sosyal kategorik benliğe ("bize" karşı "onlar", grup dışı karşı grup, kadınlar, erkekler, beyazlar, siyahlar, vb.) atıfta bulunmaktadır (Turner, Oakes, Haslam ve McGarty, 1994; Deaux, 2002; Jetten vd., 2014; Hogg vd., 2017).

Sosyal kimlik kuramı, olumlu sosyal kimliğin, insanların kendi kendini değerlendirme, geliştirme veya sürdürme anlamında motive edici olduğunu vurgulamaktadır (Karasawa, 1991; Demirtaş, 2003). Olumlu bir sosyal kimlik arzusu, iç grup ve dış grup arasında olumlu karşılaştırmalar yapılarak elde edilmektedir (Tajfel, 1982; Amiot ve Sansfaçon, 2011). Kişinin kendi grubu ile başka bir grup arasında ayrım yaparken, kişi kendi grubunu diğer gruplardan daha olumlu olarak değerlendireceğinden kişinin olumlu bir sosyal kimlik kazanacağ düşünülmektedir (Deaux, 2002; Van Knippenberg, Van Knippenberg, Monden ve De Lima, 2002). Olumlu bir sosyal kimlik, olumlu benlik saygısı ile ödüllendirilmekte, negatif bir sosyal kimlik ise sürekli rekabet, sosyal hareketlilik gibi davranışları içermektedir (Trepte ve Loy, 2017).

\section{Motosiklet Kullanıcılarının Sosyal Kimlikleri}

Sosyal grup üyeliği insanlara sosyal kimlik kazandırarak kim olduğunu tanımlayabilmektedir. Bir kişi bir grupla ilişkili olduğunda, kendini bir grubun üyesi olarak sinıflandırmaktadır (Broughton ve Walker, 2009; Veno, 2009). Bazı bireyler motosiklet kulüplerine sosyal kimlik kazanmak amaciyla girebilmektedir. Motosiklet kulübüne üyelik ve hatta alt kültür üyeliği statik değildir; ancak üyelik sırasında alt kültür normlarına uyum ve bağlılık, kulüplerin faaliyetlerinde önemli bir rol oynamaktadır (Harris, 2016). Motosikletçi, üyesi olduğu motosiklet kulübünü temsil ettiği gibi tüm motosiklet gruplarını da temsil etmektedir. Bu nedenle pek çok motosikletçi, büyük motosiklet gruplarına ait olduklarını düşünmektedir. Bu duyguyu tanıdığı veya tanımadığı diğer motosiklet sürücülerine far ya da farların parıltısı ile (selam vererek) göstermektedir (Broughton ve Walker, 2009). Özellikle yeleklerinde \%1 sembolü olan motosiklet kulüplerinin üyeleri, grubun sahip olduğu norm, görev ve sorumlulukları hayatlarında kendileri için öncelik taşıması gereken iş, sosyal yükümlülük ve ailelerinin önüne geçirebilmektedir (Harris, 2016).

Kişilerin seçtikleri motosiklet türleri ve sürüş tarzları da sosyal bir kimlik tarzını temsil etmektedir (Austin ve Gagne, 2008). Grupla birlikte sürüş yapan motosiklet kullanıcısının normal sürüş tarzından farklı bir şekilde ve grubun sahip olduğu sürüş normlarına uyarak sürüş yapması gerekmektedir. Bununla birlikte bir motosiklet kullanıcısı kendini bir motosiklet grubuna ait hissediyorsa tek başına yaptığı seyahatlerde dahi güvenli bir sürüş yaparak daha az sollama yapma eğiliminde olacaktır. Bu davranış şekli kişinin söz konusu grup üyeliği sonucunda grup normların kabul etmesinin bir yansımasıdır. Diğer taraftan grubun sahip olduğu normların üyeler üzerinde baskı yaratması ve motosiklet kullanıcısının kısıtlandığını hissetmesi üyeliğin sonlanmasına neden olabilmektedir (Broughton ve Walker, 2009). Ellemers ve diğerleri (1999) sosyal kimlik oluşumunda grup bağlllığının önemli bir belirleyici olduğunu belirtmektedir. Birbirine önemli bir bağlılığa sahip motosiklet gruplarına üye olan bireyler bu 
bağlılık sayesinde ortak hareket etmeye, grupla aynı düşüncelere sahip olmaya ve aynı şekilde düşünmeye başlamaktadır. Böylece grup üyelerinin sosyal kimlikleri bu bağlılık ve aidiyetten etkilenmektedir. Birlikte hareket etme, benzer kıyafetler giyme, benzer istek ve ihtiyaçlara sahip olma, ortak bir akıl yürütme gibi nedenler ayrıca sosyal hayatlarında yapılan bütün aktivitelerin motosiklet ve motosiklet grubuna özgü olması sosyal kimliğin etkilendiğinin en önemli sonuçlarıdır (Ertaş ve Aktaş, 2017).

Motosiklet kullanıcıları kendilerine özgü sosyal kimliklere sahiptir. Bu sosyal kimlikler her motosiklet kullanıcısı için değişmekle birlikte farklı motosiklet gruplarına üye olan motosiklet kullanıcıları için de değişebilmektedir. Örneğin içinde katı kuralları olan ve güçlü bağlılık olan gruplara üye olan bireylerin sosyal kimlikleri grubun sahip olduğu normlardan daha fazla etkilenebilmektedir. Bunun yanında sadece belirli rotalar doğrultusunda aynı grup içinde seyahat eden motosiklet kullanıcilarının sosyal kimlikleri ise grup etkisinden ziyade bireysel etkiler aracılı̆̆ıyla ortaya çıkmaktadır.

\section{YÖNTEM}

Serbest zamanlarında motosiklet ile seyahat eden ve bir gruba üye olan bireyleri konu alan bu çalışmanın amaçları;

1. Motosiklet kullanan ve bir gruba üye olan bireylerin sosyal kimliklerini ortaya çıarmak,

2. Motosiklet kullanıcılarına özgü sosyal kimlik ölçeğini geliştirmektir.

Çalışmanın örneklemini serbest zamanlarında motosiklet ile seyahat eden ve bir motosiklet grubuna üye bireyler oluşturmaktadır. Örneklem olarak motosiklet kullanıcılarının seçilmesinin nedeni hem bireysel hem de grup olarak rekreatif aktivitelere katılım sağlayan bireylerin hedef alınmasından kaynaklanmaktadır. Aynı zamanda motosiklet kullanıcıları üzerine sosyal kimlik çalışmalarının sınırlı olması, bu örneklem grubunun seçilmesinin başka bir nedenini oluşturmaktadır. Bununla birlikte çalışma günlük hayatlarında motosikleti yalnızca bir ulaşım aracı olarak kullanan bireyleri kapsamamaktadır. Araştırmanın örneklemini, uzun yol seyahatlerini motosikletleriyle yapan, en az bir yıldır bir motosiklet kulübüne üye olan, motosiklet ile uzun yol seyahat yapan, uzun yolda motosiklet gruplariyla seyahat eden ve bu seyahatlerini iş amaçları dışında serbest zamanlarında gerçekleştiren bireyler oluşturmaktadır.

Araştırma ölçek geliştirme çalışması olduğundan nitel ve nicel yöntemlerden yararlanılarak karma yöntem kullanılmıştır. Ölçek geliştirme çalışmalarında tek bir yöntem sorunun çözümünde yeterli olmadığından karma yöntemler kullanılması önerilmektedir (Patton, 2018). Punch (2016), nicel araştırmaların sıkıca yapılandırılmış olduğunu ve önceden belirlenmiş araştırma sorularını içerdiğini ifade ederken, bu araştırma desenine ulaşmak için yol gösterici genel sorulardan ve esnek yapılandırılmış nitel araştırma tasarımından faydalanılabileceğini belirtmektedir. Küçük, Yılmaz, Baydaş ve Göktaş (2014), ölçek geliştirme sürecinde ilk olarak nitel yöntemler ile başlanmasını (ör., mülakat, odak grup, vb.) ve bu yöntem doğrultusunda madde havuzunun oluşturulması gerektiğini belirtmektedir. Erkuş (2012), alan yazında var olan kaynaklarla yetinilmemesini, bu sürecin bir gömülü teori süreci olduğunu, gözlem, mülakat, vb. her türlü yola başvurulması gerektiğini belirtmektedir. Bu nedenle çalışmada ilk önce nitel yöntemlerle veri toplanmış daha sonra nicel yöntem kullanılmıştır. Ölçek geliştirme süreci şekil 1'de gösterilmektedir. 


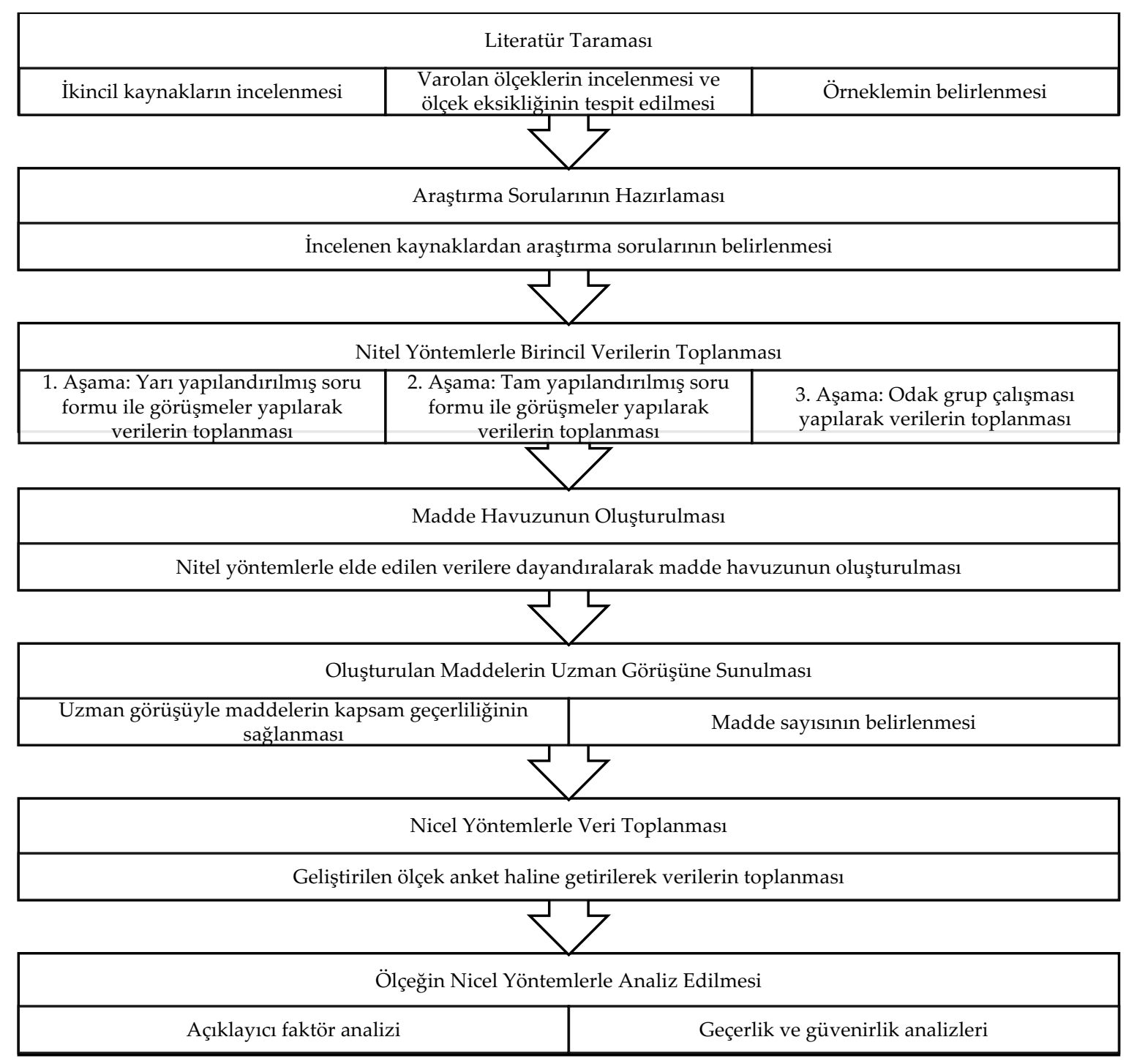

Şekil 1. Ölçek Geliştirme Süreci

Çalışmada ilk üç aşama nitel son aşama nicel olmak üzere dört aşamada veri toplanmıştır. Nitel verilerin toplanması ve analizi aşamasından Guba (1981)'ın güvenirlik, aktarılabilirlik, tutarlılık ve doğrulanabilirlik temel ölçütlerinden oluşan "güvenirlik modeli" temel alınarak veriler toplanmış ve analiz edilmiştir. Nitel yöntemlerle toplanan verilerde katılımcıların sosyal kimlikleri yaptıkları rekreatif aktiviteye ve grup üyeliklerine dair sorular üzerinden elde edilmiştir. Katılımcılara direk olarak sosyal kimliklerine etki eden unsurlar nelerdir gibi sorular sorulmamiştır.

Veri toplama sürecinin birinci aşaması yarı yapılandırılmış soru formu kullanılarak gerçekleştirilmiştir. Mülakatlar, 03.07.2017-09.12.2017 arasında aktif olarak motosiklet kullanan ve bir gruba üye olan 27 motosiklet kullanıcısıyla yapılmıştır. Araştırmada görüşme yapılacak kişilere kartopu örnekleme yöntemi ile ulaşılmıştır. Lincoln ve Guba (1985), toplanan verilerden elde edilen cevapların doygunluk noktasına ulaşılıncaya kadar veri toplamaya devam edilmesi gerektiğini belirtmektedir. Bu tür mülakatlar ayrıca, araştırmacının önceden belirlediği araştırma sorularına alternatif yanıtlar elde etmesine ve önemli olduğunu düşündüğü yanitları keşfetmesine yardımcı olmaktadır (Malhotra, 2006; Longhurst, 2010). Bununla birlikte toplanan 
verilerin güvenirlik ve geçerliklerini sağlamak amacıyla görüşmeler araştırmacı tarafından gerçekleştirilmiş ve görüşme esnasında bazı sorular katılımcılara tekrar sorularak verilen cevapların doğruluğu test edilmiştir (Shenton, 2004). Görüşmeler 47 ila 110 dakika arasında sürmüştür ve tüm görüşmelerin ortalaması 76 dakikadır. Mülakatlar yapılmadan önce görüşme yapılacak kişiler aranarak uygun oldukları gün ve saatler için randevu alındıktan sonra görüşmeler yapılmıştır. Görüşme sırasında katılımcılardan izin alınarak ses kayıt cihazı ile görüşmeler kayıt altına alınmıştır.

Veri toplama sürecinin ikinci aşaması tam yapılandırılmış soru formu kullanılarak gerçekleştirilmiştir. Soru formu bir önceki aşamada elde edilen verilerden oluşturulmuştur. Oluşturulan soruların alanında uzman üç farklı araştırmacı tarafından kontrolleri sağlandıktan sonra veri toplama süreci başlamıştır. Bir önceki aşamada elde edilen verilerden ortaya çıkan temalar olan; "Motosiklet ile seyahat etme", "Motosiklet gruplarına üyelik" ve "Motosiklet gruplarına üyeliğin devamlılığı" açık uçlu soru haline getirilerek serbest zamanlarında motosiklet ile seyahat eden ve bir motosiklet grubuna üye olan bireylerden toplanmıştır. Bu aşamada veriler, 15.12.2017-14.01.2018 tarihleri arasında amaçlı örneklem doğrultusunda sosyal medya üzerinden ulaşılan 33 katılımcıdan toplanmıştır.

Veri toplama sürecinin üçüncü aşamasında, odak grup yöntemi kullanılmıştır. Kümbetoğlu (2015), odak grup görüşmelerinin doğrudan veri toplama tekniği olarak kullanılacağ gibi, çalışma içinde kullanılan diğer veri toplama tekniklerine destek olarak da kullanılabileceğini belirtmektedir. $\mathrm{Bu}$ araştırmada, odak grup görüşmeleri diğer nitel veri toplama tekniklerinden elde edilen verilere destek olması amacıyla gerçekleştirilmiştir. Bu amaçla üç farklı odak grup çalışması yürütülmüştür. 1. odak grup çalışması, 03.02.2018 tarihinde altı kadın motosiklet kullanıcısıyla 75 dakika sürmüştür. 2. odak grup çalışması, 09.03.2018 tarihinde beş erkek motosiklet kullanıcısıyla 105 dakika sürmüştür. 3. odak grup çalışması ise 30.03.2018 tarihinde dört erkek motosiklet kullanıcısıyla 115 dakika sürmüştür. Bu aşamada, odak gruba katılacak bireylere iki soru sorulmuştur. Aynı zamanda bu aşamada birinci ve ikinci aşamada toplanan verilere uygulanan içerik analizi sonucunda oluşturulan tema, kategori ve alt kategoriler odak gruba katılan motosiklet kullanıcılarının onayına sunulmuştur. Sorular, odak gruba başlanmadan önce alanında uzman üç farklı araştırmacının görüşleri alınarak oluşturulmuştur. Odak grup çalışmalarında ilk olarak katılımcılara sırasıyla "Motosiklet gruplarıyla seyahat etmenizin nedenleri nelerdir?" ve "Motosiklet gruplariyla seyahat etmeye devam etmenizin nedenleri nelerdir?" soruları sorulmuştur. Katılımcılara kendi aralarında tartışarak sırasıyla bu sorulara verecekleri cevapları, araştırmacı tarafından verilen cevap formuna doldurmaları istenmiştir.

Araştırmanın veri toplamasının ilk üç aşamasında elde edilen veriler bir araya getirilerek nitel veri analizi yapılmıştır. Elde edilen verilerin analizinde içerik analizi tekniği kullanılmıştır. Bu araştırmada, tema, kategori ve alt kategorileri belirlemek amacıyla, verilerin analiz sürecinde önce açık kodlama sonrasında ise eksenel kodlama yapılmıştır (Corbin ve Staruss, 1990). İçerik analizi sonucunda, iki farklı araştırmacı tarafından yapılan analizlerde tutarlı bulunan tema, kategori ve alt kategoriler oluşturulmuştur. Elde edilen tema, kategori ve alt kategoriler içerik analizini yapan araştırmacılardan farklı olarak alanında uzman iki araştırmacının kontrol etmesinden sonra son halini almıştır.

Dördüncü aşamada ilk üç veri toplama aşamasında elde edilen verilerden madde havuzu oluşturulmuştur. Bu aşamada araştırmacı tarafından motosiklet ile seyahat eden ve bir gruba üye olan bireylerle yapılan görüşmelerde söyledikleri cümleler yardımıyla madde havuzu oluşturulmuştur. Toplamda 139 tane madde oluşturulmuştur. Tablo 1 madde oluşturma sürecinde uygulanan yöntemi göstermektedir. İlk madde havuzu oluşturulduktan sonra, kapsam ve dil geçerlilikleri sağlamak amacıyla bazı uygulamalar gerçekleştirilmiştir. İlk olarak iki farklı 
uzman tarafından maddeler incelenmiş ve birbirinin ayn olduğunu düşündükleri maddeleri madde havuzundan çıkarmışlardır. Daha sonra aktif olarak motosiklet kullanan bireylerden maddeleri incelemeleri istenmiştir. Madde azaltımının üçüncü aşamasında alanında uzman üç farklı araştırmacıdan görüş alındıktan sonra dördüncü aşamada maddelerin tek tek tartışılmasına olanak sağlamak amacıyla odak grup yapılmıştır. Odak grup, alanında uzman beş araştırmacı ile 21.06.2018 tarihinde gerçekleştirilmiş ve 115 dakika sürmüştür. Son olarak, maddeler motosiklet ile seyahat eden 10 kişiye gönderilmiştir. Motosiklet ile seyahat eden katılımcıların da tavsiyeleri alındıktan sonra madde havuzu son haline getirilmiştir. Son haline getirilen maddelerin oluşturduğu anket formu 30 maddeden oluşmaktadır.

Tablo 1: Madde Oluşturma Süreci Örneği

\begin{tabular}{|c|c|c|c|c|}
\hline Tema & Kategori & Alt Kategori & Alıntı & İfade \\
\hline \multirow{4}{*}{$\begin{array}{l}\text { Sosyal } \\
\text { Kimlik }\end{array}$} & Yaşam Tarzı & $\begin{array}{l}\text { Grubun } \\
\text { Değiştirdiği } \\
\text { (Arkadaşlıklar) }\end{array}$ & $\begin{array}{l}\text { Şu andaki arkadaşlarımın } \\
\text { hepsi bu motosiklet } \\
\text { grubunda tanıdığım insanlar. } \\
\text { Başka hiç kimse yok. Ne eski } \\
\text { üniversite arkadaşları ne eski } \\
\text { iş arkadaşları hiç kimse } \\
\text { kalmadı sadece grupta } \\
\text { tanıdığım insanlar var } \\
\text { hayatımda. (Katılımcı 4) }\end{array}$ & $\begin{array}{l}\text { Motosiklet } \\
\text { grubundan sonra } \\
\text { arkadaş ortamım } \\
\text { değişti. }\end{array}$ \\
\hline & $\begin{array}{l}\text { Motosiklet } \\
\text { Kullanmanın } \\
\text { Kazanımları }\end{array}$ & Disiplin & $\begin{array}{l}\text { Motosiklet kullandığım için } \\
\text { vücudum dirençli. Soğuğa, } \\
\text { sıcağa belli bir süre sonra } \\
\text { alışıyorsun. Motosiklet } \\
\text { dayanıklılığı arttırır. Bir kere } \\
\text { sinirlerinin çelik gibi kuvvetli } \\
\text { olmasını sağllyor. Disipline } \\
\text { ediyor. (Katılımcı 27) }\end{array}$ & $\begin{array}{l}\text { Motosiklet ile } \\
\text { seyahat ettiğim } \\
\text { için disiplinli bir } \\
\text { bireyim. }\end{array}$ \\
\hline & $\begin{array}{l}\text { Güvenliğe } \\
\text { Önem }\end{array}$ & Tam koruma & $\begin{array}{l}\text { Her şeyden önce motosikletçi } \\
\text { tam donanım ile motosiklet } \\
\text { sürüşü yapmalı çünkü tam } \\
\text { donanımın beni gerçekten } \\
\text { kurtardığını bildiğim için } \\
\text { özellikle kask hikâyesinin } \\
\text { çok önemli olduğunu, } \\
\text { kasksız hiçbir } \\
\text { motosikletçinin bakkala bile } \\
\text { gitmemesi gerektiğini } \\
\text { bilirim. (Katılımcı 16). }\end{array}$ & $\begin{array}{l}\text { Motosikletçi } \\
\text { koruma sağlayan } \\
\text { donanım (kask, } \\
\text { dizlik vb.) ile } \\
\text { seyahat eder. }\end{array}$ \\
\hline & Özgürlük & $\begin{array}{l}\text { Cesur kararlar } \\
\text { alma }\end{array}$ & $\begin{array}{l}\text { Motosikletçi hem yolda } \\
\text { kararlı olmalı yola bakmada } \\
\text { hem de öz güvenli olmalıdır. } \\
\text { Kararlarının arkasında } \\
\text { durmalı, cesur olmadır, bir } \\
\text { yerden geçmesi gerekiyorsa } \\
\text { kararlılıkla geçmeli tereddüt } \\
\text { etmemelidir. (Katılımcı 23) }\end{array}$ & $\begin{array}{l}\text { Motosikletçi } \\
\text { aldığı kararlarda } \\
\text { cesurdur. }\end{array}$ \\
\hline
\end{tabular}




\begin{tabular}{|c|c|c|c|}
\hline $\begin{array}{l}\text { Grubun } \\
\text { Sağladığ1 } \\
\text { Kazanımlar }\end{array}$ & Zindelik & $\begin{array}{l}\text { Grupla gittiğimde kendimi } \\
\text { daha zinde hissediyorum, } \\
\text { çünkü iş ortamı değil bu } \\
\text { resmi bir şey de değil bu } \\
\text { gönül birlikteliği beraber } \\
\text { aynı zevki paylaşıyoruz aynı } \\
\text { sürüşü yapıyoruz. (Katılımcı } \\
\text { 6) }\end{array}$ & $\begin{array}{l}\text { Motosiklet grubu } \\
\text { sayesinde } \\
\text { stresim azalır. }\end{array}$ \\
\hline Bağlilık & Öncelik & $\begin{array}{l}\text { Motosiklet grubu ve } \\
\text { arkadaşlarım silahın önüne } \\
\text { geçebilecek kadar değerlidir. } \\
\text { Onlar vurulacağına ben } \\
\text { vurulayım, ben vurulacağım } \\
\text { zaman onlar da aynısını } \\
\text { düşünür, o kadar bağlıyız } \\
\text { biz. (Katılımc1 2) }\end{array}$ & $\begin{array}{l}\text { Motosikletçi için } \\
\text { motosiklet grubu } \\
\text { her şeyden önce } \\
\text { gelir. }\end{array}$ \\
\hline $\begin{array}{l}\text { Kendini } \\
\text { Geliştirme }\end{array}$ & $\begin{array}{l}\text { Sürekli } \\
\text { eğitimler }\end{array}$ & $\begin{array}{l}\text { Grup içinde olduğun zaman } \\
\text { bugün bu eksiğim var } \\
\text { diyorum yarına onu } \\
\text { tamamliyorum başka bir } \\
\text { eksikliğim çıkıyor. Meslek } \\
\text { gibi düşünün. Devamlı } \\
\text { kendinizi geliştirmeniz } \\
\text { gerekiyor. Grup içinde } \\
\text { eğitimlerimiz } \\
\text { (Katılımcı 14) }\end{array}$ & $\begin{array}{l}\text { Motosikletçi } \\
\text { grup içinde her } \\
\text { anlamda kendini } \\
\text { geliştirme } \\
\text { imkânı bulur. }\end{array}$ \\
\hline
\end{tabular}

Veri toplama sürecinin son aşamasını nicel yöntem oluşturmaktadır. Bu aşamada aktif olarak motosiklet kullanan ve motosiklet grubuna üye olan bireylerden 486 adet anket toplanmıştır. Bu anketlerin 293 tanesi, 2-6 Ağustos 2018 tarihleri arasında Balıkesir Cunda'da düzenlenen 8. Balıkesir Motosiklet Festivali'nde toplanmıştır. Festival süresince 400 anket dağıtılmasına karşın, 314 anket geri toplanmıştır. Bu anketlerden kullanılabilir olan 293 anket analize dâhil edilmiştir.

193 tane anket ise, 8-25 Ağustos 2018 tarihleri arasında Google Formlar üzerinde oluşturulan anket formu ile motosiklet kullanıcılarına ve motosiklet gruplarına sosyal medya hesaplarından ulaşılarak elde edilmiştir. Bu aşamada da 198 anket elde edilmiş olmasına karşın kullanılabilir olduğuna inanılan 193 anket analize dâhil edilmiştir. İki aşamada toplanan toplam 486 anket ile analizler gerçekleştirilmiştir. Bu araştırmada, örneklem sayısı G*Power 3.1 örneklem hesaplama robotu ile belirlenmiştir (Faul, Erdfelder, Lang ve Buchner, 2007). Bu program örneklem sayısını, \%5 güven aralığında 472 olarak belirlemektedir. Bu nedenle araştırmada, 486 adet anket toplanmıştır. Anketlerin tamamı araştırmacı tarafından toplanmıştır. Motosiklet festivalinde olasılıklı örnekleme türlerinden biri olan basit rastgele örneklem türü ile katılımcılardan veriler toplanmıştır. Anketler katılımcılara verilmeden önce bir motosiklet grubuna üye olup olmadıkları ve aktif olarak motosiklet kullanıp kullanmadıkları sorulmuş, bu ölçütleri sağlayan kişiler araştırmaya dâhil edilmiştir. Ayrıca anketler katılımcılara verilmeden önce ankete katılmak isteyip istemedikleri de sorulmuş ve katılmak isteyenlere anket formu verilmiştir. Araştırmada Likert tipi ölçek kullanılmıştır. Bu amaçla araştırmada 5'li likert ölçeği kullanılmıştır (1=Kesinlikle Katılmiyorum, 2=Katılmiyorum, 3=Ne Katıliyorum $\mathrm{Ne}$ Katılmiyorum, 4=Katılıyorum, 5= Kesinlikle Katılıyorum). Anketin son bölümünde motosiklet ile seyahat eden 
bireylerin profillerini belirlemeye yönelik tanımlayıcı sorulara yer verilmiştir. Verilerin analizinde ise SPSS 24 veri analizi programı kullanılmıştır.

\section{BULGULAR}

Bu bölümde çalışmada kullanılan ankete katılan kişilerin demografik özelliklerine yer verilmiştir (Tablo 3). Ankete katılan motosiklet kullanıcılarının önemli bir kısmının 18-50 yaş aralığında $(\% 84,4)$ ve 5 yıldan fazladır aktif olarak motosiklet kullandığ $(\% 63,7)$, grupla birlikte seyahat yıllarının 1 ila 5 aralığında olduğu (\%68,7), grupla birlikte ortalama yılda 5 seferden fazla seyahat ettikleri $(\% 70,6)$ ve yılda $5000 \mathrm{Km}$ 'den fazla yol yaptıkları sonucuna ulaşılmıştır $(\% 77,5)$.

Sosyal kimlik ölçeğinin yapısal geçerliğini test etmek ve ölçeğin kaç faktör olduğunu belirlemek amaciyla, Horn' un (1965) Paralel Analizi (HPA), Velicer'in (1976) Kısmi Minimum Ortalama Analizi (Minimum Average Partial [MAP]) ve Cattell'in (1966) Çizgi Grafiği (Scree Plot) kullanılmıştır. Horn'un (1965) paralel analiz testi ve Cattell'in (1966) çizgi grafiği analizleri, ölçeğin yedi faktör olduğunu, Velicer's (1976) kısmi minimum ortalama analiz testi ise ölçeğin üç faktör olduğunu belirtmiştir. Sosyal kimlik ölçeği, anket haline getirilmeden önce nitel veri toplama yöntemleriyle elde edilen verilerin içerik analizinde sekiz kategori elde edilmiştir. Bu sekiz kategoriden biri olan "kişilik özellikleri" için oluşturulan ifadelerin tamamı madde havuzu oluşumunda uzman görüşmeleri sonucunda araştırmadan çıkarıldığından ölçeğin anketi yedi kategori üzerinden tasarlanmıştır. İçerik analizinde de yedi kategori olması nedeniyle konuyu açıklamaya en uygun olanın yedi faktör olacağı düşünüldüğünden, açıklayıcı faktör analizinde (PAF) ölçek yedi faktör ile sınırlandırılmıştır.

Açıklayıcı faktör analizinde, faktörlerin yapısını belirlemek amacıyla, temel eksen faktör çıkarım yöntemi kullanılmıştır. Döndürme yöntemi olarak ise "promax" döndürme yöntemi kullanılmıştır. Temel eksen faktör çıkarım yöntemi, ölçekteki bazı ifadelerin basıklık ve çarpıklık değerlerinin istenilen düzeyde olmamasından dolayı kullanılmıştır (Fabrigar, Wegener, MAcCallum ve Strahan, 1999; Fabrigar ve Wegener, 2012; Karaman, Atar ve Çobanoğlu-Aktan, 2017). Promax döndürme yöntemi kullanılmasının nedeni ise sosyal kimlik ölçeğinde ortaya çıkan faktörler arasındaki korelasyonun istenilen düzeyde olmasıdır (Mvududu ve Sink, 2013; Hair, Black, Babin ve Anderson, 2014; Tabachnick ve Fidell, 2015).

Sosyal kimlik ölçeğine yapılan faktör analizi sonucunda ölçeğin geçerliği için kullanılan KMO değeri, ,90 olarak bulunmuştur. Bu değer, Kaiser (1974)'in KMO için yaptığı sinıflandırma temel alındığından mükemmel olarak ortaya çıkmıştır. Ayrıca ölçeğin yakınsak ve ayrımsama geçerlikleri de sağlanmıştır. Bununla birlikte ölçeğin güvenirliği için kullanılan Cronbach'ın alfa değeri ise ,91 olarak bulunmuştur. Bu değer, Hair ve diğerleri (2014)'in Cronbach alfa için belirttiği düzeyin üstünde çıkmıştır. Bu nedenle sosyal kimlik ölçeği güvenilir ve geçerlidir. Ölçeğin faktör analizi Tablo 2'de gösterilmektedir. 
Tablo 2. Ankete Katılan Kişilerin Demografik Özellikleri

\begin{tabular}{|c|c|c|}
\hline Demografik Özellikler & Say1 & Ortalama \\
\hline \multicolumn{3}{|l|}{ Motosiklet Kullanma Yılı } \\
\hline $1-5$ & 164 & 36,3 \\
\hline $6-10$ & 96 & 21,3 \\
\hline $11-15$ & 63 & 14,0 \\
\hline 16 ve üzeri & 128 & 28,4 \\
\hline Toplam & 451 & 100 \\
\hline \multicolumn{3}{|l|}{ Grupla Seyahat Y11 } \\
\hline $1-5$ & 284 & 68,7 \\
\hline $6-10$ & 84 & 20,3 \\
\hline 11 ve üzeri & 45 & 11,0 \\
\hline Toplam & 413 & 100 \\
\hline \multicolumn{3}{|l|}{ Son Grupla Seyahat Yılı } \\
\hline $1-5$ & 320 & 78,8 \\
\hline $6-10$ & 61 & 15,0 \\
\hline $11-15$ & 25 & 6,2 \\
\hline Toplam & 406 & 100 \\
\hline \multicolumn{3}{|c|}{ Motosiklet Grubu ile Ortalama Yıllık Seyahat } \\
\hline $1-4$ & 117 & 29,4 \\
\hline $5-10$ & 177 & 44,6 \\
\hline 11 ve üzeri & 103 & 26,0 \\
\hline Toplam & 397 & 100 \\
\hline \multicolumn{3}{|c|}{ Motosiklet ile Yapılan Ortalama Yıllık Kilometre } \\
\hline $1000-5000 \mathrm{Km}$ & 97 & 22,5 \\
\hline $5001-10000 \mathrm{Km}$ & 148 & 34,4 \\
\hline $10001-15000 \mathrm{Km}$ & 80 & 18,6 \\
\hline $15001 \mathrm{Km}$ ve üzeri & 105 & 24,5 \\
\hline Toplam & 430 & 100 \\
\hline \multicolumn{3}{|l|}{ Yaş } \\
\hline $18-30(1)$ & 164 & 34,0 \\
\hline $31-40(2)$ & 142 & 29,6 \\
\hline $41-50(3)$ & 100 & 20,8 \\
\hline 51 ve üzeri (4) & 75 & 15,6 \\
\hline Toplam & 481 & 100 \\
\hline \multicolumn{3}{|l|}{ Motosiklete İlgi } \\
\hline Çocukluğumda Başladı & 263 & 54,6 \\
\hline Ailemden Gelmekte & 58 & 12,0 \\
\hline Merak & 151 & 31,3 \\
\hline Başkalarına Özenme & 10 & 2,1 \\
\hline Toplam & 482 & 100 \\
\hline \multicolumn{3}{|l|}{ Cinsiyet } \\
\hline Kadın & 85 & 17,6 \\
\hline Erkek & 399 & 82,4 \\
\hline Toplam & 484 & 100 \\
\hline
\end{tabular}


Tablo 2. Sosyal Kimlik Ölçeği Faktör Analizi

\begin{tabular}{|c|c|c|c|c|}
\hline FAKTÖRLER & $\begin{array}{l}\text { Faktör } \\
\text { Yükü }\end{array}$ & $\begin{array}{l}\text { Öz } \\
\text { Değer }\end{array}$ & $\begin{array}{l}\text { Açılanan } \\
\text { Varyans }\end{array}$ & Ort. \\
\hline Faktör 1: Yaşam Tarzı & & 7,975 & 31,902 & 3,62 \\
\hline Motosiklet grubundan sonra arkadaş ortamım değişti. & ,921 & & & \\
\hline $\begin{array}{l}\text { Motosiklet grubundan sonra daha sosyal bir insan } \\
\text { oldum. }\end{array}$ & ,748 & & & \\
\hline $\begin{array}{l}\text { Motosiklet grubundan sonra görünümüm (saç, sakal, } \\
\text { giyim tarzı) değişti. }\end{array}$ & ,696 & & & \\
\hline $\begin{array}{l}\text { Motosiklet grubundan sonra daha fazla seyahate } \\
\text { çıkmaya başladım. }\end{array}$ & ,638 & & & \\
\hline Motosiklet grubundan sonra yaşam tarzım değişti. &, 503 & & & \\
\hline Faktör 2: Motosiklet Kullanımının Kazanımları & & 2,561 & 10,245 & 4,36 \\
\hline Motosiklet ile seyahat ettiğim için disiplinli bir bireyim. & 900 & & & \\
\hline $\begin{array}{l}\text { Motosiklet ile seyahat ettiğim için sorumluluk sahibi bir } \\
\text { bireyim. }\end{array}$ & ,888 & & & \\
\hline Motosiklet ile seyahat ettiğim için dengeli bir bireyim. & ,686 & & & \\
\hline Motosiklet ile seyahat ettiğim için dikkatli bir bireyim. & 645 & & & \\
\hline Faktör 3: Güvenliğe Önem & & 1,339 & 5,355 & 4,62 \\
\hline $\begin{array}{l}\text { Motosikletçi koruma sağlayan donanım (kask, dizlik } \\
\text { vb.) ile seyahat eder. }\end{array}$ & ,911 & & & \\
\hline Motosikletçi kurallara uyar. &, 762 & & & \\
\hline Motosikletçi seyahatlerde güvenliğe önem verir. &, 542 & & & \\
\hline Motosikletçi yolda kalmış birine yardım eder. & 421 & & & \\
\hline Faktör 4: Özgürlük & &, 886 & 3,545 & 4,64 \\
\hline Motosikletçi aldığı kararlarda cesurdur. & 856 & & & \\
\hline Motosikletçi kendine güvenir. &, 825 & & & \\
\hline Motosikletçinin ruhunda özgürlük vardır. &, 572 & & & \\
\hline Faktör 5: Grubun Sağladığı Kazanımlar & & ,716 & 2,863 & 4,14 \\
\hline Motosiklet grubu sayesinde stresim azalır. & 801 & & & \\
\hline Motosiklet grubu sayesinde pozitif enerji depolarım. & ,755 & & & \\
\hline $\begin{array}{l}\text { Motosiklet grubu sayesinde işime daha çok konsantre } \\
\text { olurum. }\end{array}$ & ,558 & & & \\
\hline Faktör 6: Bağlılık & &, 560 & 2,240 & 3,40 \\
\hline Motosikletçi için motosiklet grubu her şeyden önce gelir. & ,834 & & & \\
\hline $\begin{array}{l}\text { Motosikletçi için motosiklet ile seyahat etmek her } \\
\text { şeyden önce gelir. }\end{array}$ & ,624 & & & \\
\hline $\begin{array}{l}\text { Motosikletçi her zaman bir grup içinde olma ihtiyacı } \\
\text { duyar. }\end{array}$ & ,409 & & & \\
\hline Faktör 7: Kendini Geliştirme & & 481 & 1,923 & 4,42 \\
\hline $\begin{array}{l}\text { Motosikletçi grup içinde her anlamda kendini geliştirme } \\
\text { imkânı bulur. }\end{array}$ & ,747 & & & \\
\hline Motosikletçi tecrübelerini arkadaşlarıyla paylaşır. & ,626 & & & \\
\hline $\begin{array}{l}\text { Motosikletçi hayat boyu sürüş eğitimi almaya devam } \\
\text { eder. }\end{array}$ & ,350 & & & \\
\hline
\end{tabular}

Faktör çıkarım yöntemi: Temel Eksenler Faktör Yöntemi

Faktör çıkarım yöntemleriyle sosyal kimlik ölçeğinin toplam açıklanan varyans değeri, ,69 olarak bulunurken, paylaşılan toplam varyans değeri, ,58 olarak bulunmuştur. Bu değerler, Comrey ve Lee (1992) için çok iyi düzeyde, Hogarty, Hines, Kromrey, Ferron ve Mumford (2005)'e göre geniş düzeyde, Hair ve diğerleri (2014) ve Tinsley ve Tinsley (1987)'e göre ise kabul edilebilir düzeyde olduğu söylenebilir. 
Sosyal kimlik ölçeğinin faktör yüklerinin sınırını belirlemek amacıyla, Norman ve Streiner (1998)'in formülü $\left(x=\frac{5,152}{\sqrt{\mathrm{N}-2}}\right)$ kullanılmıştır ( $\mathrm{N}$ : örneklem sayısı). Bu formül, ,23'ün üstündeki ifadelerin araştırmadan çıkarılmamasını önermektedir. Ölçekteki tüm ifadelerin faktör yükleri istenilen düzeyin üzerindedir (Hair vd., 2014; Tabachnick ve Fidell, 2015).

Sosyal kimlik ölçeğinde veriler 30 ifade üzerinden toplanmıştır. Ancak açıklayıcı faktör analizi sonucunda, 5 ifade araştırmadan çıkarılmıştır. Araştırmadan çıkarılan ifadeler:

S8: Motosikletçi grubunun yaptığı seyahatlere katılmadığında üzülür.

S9: Motosikletçi grubuyla seyahat etmekten mutluluk duyar.

S21: Motosiklet ile seyahat etmek sağlıklı bir birey olmamı sağlar.

S22: Motosiklet ile seyahat etmek dayanıklı bir birey olmamı sağlar.

S23: Motosiklet ile seyahat etmek reflekslerimi geliştirir.

Bu ifadelerin araştırmadan çıkarılma nedenleri, S8, S9, S21 ve S23 ifadelerinin tek başına faktör olarak ortaya çıkması ve S22 ifadesinin birden fazla faktöre birbirine yakın faktör yükü vermesinden kaynaklanmaktadır. Araştırmacılar, her ortak faktörü temsil eden en az üç ila beş ölçüm değişkeninin olması gerektiğini belirtmektedir (Velicer ve Fava, 1998; Fabrigar vd., 1999; MacCallum, Widaman, Zhang ve Hong, 1999). Diğer taraftan faktör analizinde birbirine yakın faktör yükleri veren ifadelerin çıarılması önerilmektedir (Büyüköztürk, 2005).

Açıklayıcı faktör analizinden önce sosyal kimlik ölçeği yedi faktör 30 ifade olarak tasarlanmıştır. Bazı ifadeler açıklayıcı faktör analizi sonucunda çıkarılmış olsa da ölçek tasarlandığı şekildeki faktör sayısına ulaşmıştır. Analizler sonucunda, sosyal kimlik ölçeği yedi faktör 25 ifade olarak gerçekleşmiştir.

\section{TARTIŞMA, SONUÇ VE ÖNERILLER}

Motosiklet ile seyahat eden ve bir motosiklet grubuna üye olan bireylerin sosyal kimliklerinin motosiklet ile seyahat etme aktivitesi, motosiklet grubuna üyelik ve motosiklet gruplarına bağlllık ve aidiyet motosiklet kullanan bireylerin sosyal kimliklerinin önemli belirleyicileri olduğu sonucuna ulaşılmıştır. Motosiklet kullanımının kazanımları, güvenliğe önem, özgürlük, grubun sağladığı kazanımlar, kendini geliştirme, bağlılık ve yaşam tarzı motosiklet kullanıcılarının sosyal kimliğini etkilemektedir.

Serbest zamanlarında motosiklet ile seyahat etme aktivitesine katılımın, motosiklet kullanıcılarının sosyal kimliğini önemli bir şekilde etkilediği sonucuna ulaşılmıştır. Bu sonuç, Jones (2000) ve Green ve Jones (2005) araştırmalarında ulaşılan sonuçlarla benzerlik taşımaktadır. Araştırmacılar, ciddi serbest zaman aktivitesinin katılımcılara güçlü bir sosyal kimlik sağladığını belirtmektedir. Bununla birlikte motosiklet ile seyahat eden bireylerin bu rekreatif aktiviteyi gerçekleştirmeleri sonucunda sosyal kimliklerini özgürlük duygusunun etkilediği ortaya çıkmıştır. Motosiklet kullanıcılarının motosiklet ile seyahat etmelerinin de nedenleri arasında olan özgürlük duygusu motosiklet kullanıcılarının daha özgüvenli olmasını ve aldığı kararlarda cesur bir şekilde davranmasını sağlamaktadır. Özgüven ve kararlılık motosiklet kullanıcıları için seyahat sırasında olması gereken en önemli özelliklerden bazılarıdır. Seyahat sırasında sürüş halinde ortaya çıkacak bir sorunda özgüven eksikliği ve kararsızlık kazalara sebep olabileceğinden, motosiklet kullanıcısının sürüş esnasında özgüvenli ve kararlı olmasını gerektirmektedir. Bu durum motosiklet kullanıcılarının sosyal kimliğine yansıyarak sadece 
motosiklet ile sürüş esnasında değil aynı zamanda yaşamlarının farklı alanlarında da özgüvenli ve kararlı olmalarını sağlamaktadır.

Motosiklet kullanıcılarının sosyal kimliklerini etkileyen diğer bir önemli unsur güvenliğe verdikleri önem olarak ortaya çıkmıştır. Motosiklet kullanıcılarının, motosiklet ile seyahatlerinde tam koruma ile yola çıktıkları, kurallara uydukları, seyahatlerinde güvenliğe önem verdikleri ve yolda kalmış bir motosiklet kullanıcısına yardım ettikleri sonucuna ulaşılmıştır. Bunları yerine getirmeyen diğer motosiklet kullanıcılarını ise motosikletçi olarak tanımlamamaktadırlar. Bazı motosiklet kullanıcıları, kasklarını kollarına takarak seyahat etmekte ve güvenlikleri için gerekli donanımları kullanmamaktadır. Bu şekilde seyahat eden motosiklet kullanıcıları, toplum arasında farklı algılara neden olduğundan, motosikleti gerekli tedbirleri alarak ve kurallara uyarak kullanan kişiler tarafından motosikletçi olarak görülmemektedir.

Motosiklet kullanıcılarının grup içinde kendilerini geliştirme imkânı bulması sosyal kimliklerini etkilemektedir. Motosiklet kullanıcılarının grup içinde diğer motosiklet kullanıcılarıyla sürekli fikir alışverişi yapabilmesi, deneyimlerini birbirlerine aktarabilmesi ve sürekli eğitimler yoluyla kendilerini geliştirebilmeleri sosyal kimliklerini etkilemektedir. $\mathrm{Bu}$ nedenle motosiklet kullanıcıları, grup sürüşlerinde diğer arkadaşlarıyla sürüş anlamında aynı seviyeye gelmek, motosikletin mekanik donanımları hakkında daha fazla bilgi sahibi olmak ve daha fazla seyahat rotası öğrenebilmek adına kendini sürekli geliştirmeyi hedeflemektedir.

Serbest zamanlarını motosiklet grupları içinde değerlendiren motosiklet kullanıcıları, grupları sayesinde daha sağlıklı bir hayat yaşamaktadır. Grup arkadaşlarıyla yaptıkları etkinlikler ve seyahatler motosiklet kullanıcılarına pozitif enerji vermekte ve streslerini azaltmaktadır. Bu durum motosiklet kullanıcılarının sosyal kimliğini etkileyen başka bir unsurdur. Jetten ve diğerleri (2014), sosyal gruba üye olan bireylerin iyi bir psikolojiye sahip oldukların, bir gruba üye olmayan bireylerden daha sağlıklı ve daha uzun yaşadıkları belirtmektedir. Cruwys ve diğerleri (2014), sosyal kimlik süreçlerinin kişilerin depresyonla başa çıkmasında önemli rolü olduğunu belirtmektedir. Bu araştırmada ise benzer şekilde, grup üyeliği motosiklet kullanıcılarının sosyal kimliklerini etkileyerek daha sağlıklı ve mutlu bir hayat sürmelerine yardımcı olmaktadır.

Motosiklet kullanıcılarının sosyal kimliğini, bireyin motosikletine ve motosiklet grubuna duyduğu bağlılık ve motosiklet grubundan sonra değişen yaşam tarzı etkilemektedir. Hoyle ve Crawford (1994), bir gruba bağlllı̆̆ın grup üyelerinin yaşamlarına etkisinin olduğunu belirtmektedir. Harris (2016), motosiklet grubu üyelerinin grup normlarını hayatlarında öncelik haline getirdiklerini ve üyelerin belirgin bir sosyal kimlik kazandıklarını belirtmektedir. Özellikle bazı motosiklet grubu üyelerinin gruplarına bağlılığı, sosyal yükümlülükleri ve ailelerinin önüne geçebilmektedir. Motosiklet kullanıcılarının büyük çoğunluğu motosiklet ile seyahat etmeyi oldukça önemsemektedir. Bu nedenle bireyler serbest zamanlarının neredeyse tamamını motosiklet ile seyahate ayırmaktadır. Bununla birlikte motosiklet kullanıcıları, motosikletlerine duydukları kadar motosiklet gruplarına da bağlılık hissetmektedir. Bu bağllılı sonucunda, motosiklet kullanıcılarının arkadaş ortamının değiştiği, motosiklet grubuyla daha fazla seyahate çıktığı, daha fazla sosyalleştiği ve özellikle yaşam tarzlarının önemli ölçüde değişsiği sonucuna ulaşılmıştır. Benzer şekilde Harris (2016), motosiklet gruplarına üye bireylerin sergiledikleri davranışlar ve giydikleri kıyafetler ve sahip oldukları ritüellerle farklı bir yaşam tarzına sahip oldukları sonucuna ulaşmıştır.

Sosyal kimlik konusunda yapılan araştırmalarda sosyal kimliğin oluşmasında grup üyeliğinin etkili olduğu sonucuna ulaşılmıştır (Cruwys, 2014; Jetten vd., 2014). Aynı zamanda geçmiş araştırmalarda, gruplara bağlılık ve aidiyet duygusunun da sosyal kimliği etkilediği görülmüştür (Ashforth ve Mael, 1989; Swann ve Bosson, 2010; Ellemers, 2012; Hogg vd., 2017). Bu araştırmada, 
önceki araştırmaların ulaştığı sonuçlara ek olarak, yapılan rekreatif faaliyetin, deneyim paylaşmanın ve grubu temsil etmenin de sosyal kimliği etkilediği ortaya çıkmıştır. Ayrıca önceki araştırmalardan farklı olarak, sosyal kimliğin kişilerin psikolojik iyi oluşlarını ve sağlıklarını olumlu yönde etkilediği sonucuna ulaşılmıştır.

Bir gruba üye bireyler olumlu bir sosyal kimlik arayışı içindedir. Olumlu bir sosyal kimliğe sahip bireyler gruplarında kalmaya devam etmekte ve bunu karşılayamadığı zamanlarda ise grup üyeliğinden ayrılmaktadır (Tajfel, 1981). Bu araştırmada, motosiklet kullanıcılarının grup üyesi olma ve grup üyeliklerinin devamlılıklarının nedenleri arasında sosyal kimlik arayışı ortaya çıkmamıştır. Ancak grup üyeliğinin önemli bir nedeni, sosyal kimlik arayışı, grup üyeliğinin devamlılığının nedeni ise elde edilen olumlu sosyal kimliği kaybetmeme isteği olabilmektedir. Bununla birlikte araştırma tek bir rekreatif grup üzerinden yürütülmüştür. Bu nedenle sosyal kimliğin her rekreatif grup üzerinde farklı olacağı düşünüldüğünden sosyal kimlik ölçeğinin tüm rekreatif gruplar üzerinde aynı sonuçları vermeyeceği varsayılmaktadır. Ayrıca motosiklet ile seyahat etme özelinde, kadın motosiklet kullanıcılarının sayısının erkek motosiklet kullanıcısı sayısından daha az olduğu belirlenmiştir. Bu nedenlerle ileride yapılacak araştırmalarda sosyal kimliğin grup üyeliği ve devamlılığına etkisi, diğer rekreatif grupların grup üyeliği, grup üyeliğinin devamlılığı ve sosyal kimliklerinin ortaya çıkarılması ve kadın motosiklet kullanıcılarının sayısının azlığının nedenleri üzerine araştırmaların gerçekleştirilebileceği düşünülmektedir.

Motosiklet ile seyahat eden bireylerin bu aktiviteyi hayat tarzı haline getirmeleri ve bunun sonucunda sosyal kimliklerini geliştirmeleri araştırmanın önemli somut çıktıları arasındadır. Bununla birlikte motosiklet ve gruplariyla seyahat etmenin kişinin hem mental hem de fiziksel sağlığına olumlu etkileri olduğu ortaya çıkmıştır. Kişilerin motosiklet ile seyahat etmeleri ve bir motosiklet grubuna üye olmaları stresten uzaklaşmalarını, pozitif enerji almalarını, işlerine olan konsantrelerinin artmasını, disiplinli, sorumluluk sahibi, dengeli ve dikkatli bireyler olmalarını sağlamaktadır.

\section{KAYNAKÇA}

Amiot, C. E. and Sansfaçon, S. (2011). Motivations to Identify with Social Groups: A Look at Their Positive and Negative Consequences, Group Dynamics: Theory, Research, and Practice, 15(2): 105127.

Arkonaç, S. A. (2008). Sosyal Psikolojide İnsanları Anlamak: Deneysel ve Eleştirel Yaklaşımlar, Ankara: Nobel Yayıncilik.

Ashforth, B. E. and Mael, F. (1989). Social Identity Theory and the Organization, Academy of Management Review, 14(1): 20-39.

Austin, D. M. and Gagné, P. (2008). Community in a Mobile Subculture: The World of the Touring Motorcyclist, Studies in Symbolic Interaction, 30: 411-437.

Brewer, M. B. and Gardner, W. (1996). Who is This" We"? Levels of Collective Identity and Self Representations, Journal of Personality and Social Psychology, 71(1): 83-93.

Broughton P. and Walker L. (2009). Motorcycling and Leisure Understanding the Recreational PTW Rider. New York: CRC Press.

Büyüköztürk, Ş. (2005). Sosyal Bilimler için Veri Analizi El Kitabı: İstatistik, Araştırma Deseni, SPSS Uygulamaları ve Yorum, Ankara: Pegem Akademi Yayıncilık. 
Cattell, R. B. (1966). The Scree Test for The Number of Factors, Multivariate Behavioral Research, 1(2): 245-276.

Comrey, A. L. and Lee, H. B. (1992). A First Course in Factor Analysis. (2. Edition), New Jersey: Psychology Press.

Corbin, J. and Strauss, A. (1990). Grounded Theory Research: Procedures, Canons, and Evaluative Criteria, Qualitative Sociology, 13(1): 3-21.

Cruwys, T., Haslam, S. A., Dingle, G. A., Haslam, C. and Jetten, J. (2014). Depression and Social Identity: An integrative review, Personality and Social Psychology Review, 18(3): 215-238.

Deaux, K. (2002). Social Identity, (Editör) Worell, J.: Encyclopedia of Women and Gender Sex Similarities and Differences and the Impact of Society on Gender içinde (ss. 1059-1068). USA: Academic Press.

Demirtaş, H. A. (2003). Sosyal Kimlik Kuramı, Temel Kavram ve Varsayımlar, İletişim Araştırmaları, 1(1): 123-144.

Ellemers, N. (2012). The Group Self, Science, 336(6083): 848-852.

Ellemers, N., Kortekaas, P. and Ouwerkerk, J. W. (1999). Self-Categorization, Commitment to the Group and Social Self-Esteem as Related but Distinct Aspects of Social Identity, European Journal of Social Psychology, 29(2-3): 371-389.

Erkuş, A. (2012). Varolan Ölçek Geliştirme Yöntemleri ve Ölçme Kuramları Psikolojik Ölçek Geliştirmede Ne Kadar İşlevsel: Yeni bir Öneri, Eğitimde ve Psikolojide Ölçme ve Değerlendirme Dergisi, 3(2): 279-290.

Ertaş, M. ve Aktaş, G. (2017). Sosyal Kimlik Kuramı: Motosiklet Kullanıcılarının İncelenmesi. 4. Rekreasyon Araştırmaları Kongresi. 12 Kasım 2017. Kuşadası. ss: 239-247.

Fabrigar, L. R. and Wegener, D. T. (2012). Exploratory Factor Analysis Understanding Statistics, New York: Oxford University Press.

Fabrigar, L. R., Wegener, D. T., MacCallum, R. C. and Strahan, E. J. (1999). Evaluating the Use of Exploratory Factor Analysis in Psychological Research, Psychological Methods, 4(3): 272-299.

Faul, F., Erdfelder, E., Lang, A. G. and Buchner, A. (2007). G*Power 3: A Flexible Statistical Power Analysis Program for the Social, Behavioral, and Biomedical Sciences, Behavior Research Methods, 39(2): 175-191.

Green, B. C. and Jones, I. (2005). Serious Leisure, Social Identity and Sport Tourism, Sport in Society, 8(2): 164-181.

Guba, E. G. (1981). Criteria for assessing the trustworthiness of naturalistic inquiries, Educational Communication and Technology, 29(2): 75-91.

Hair, J. F., Black, W. C., Babin, B. J. and Anderson, R. E. (2014). Multivariate Data Analysis. (17. Edition), Edinburg: Pearson.

Harris, K. J. (2016). The Fierce Commitment to 1\% Motorcycle Clubs, Journal of Policing, Intelligence and Counter Terrorism, 11(1): 73-83.

Haslam, S. A., Jetten, J., Postmes, T., and Haslam, C. (2009). Social Identity, Health and WellBeing: An Emerging Agenda for Applied Psychology, Applied Psychology: An International Review, 58(1): 1-23. 
Hogarty, K. Y., Hines, C. V., Kromrey, J. D., Ferron, J. M. and Mumford, K. R. (2005). The Quality of Factor Solutions in Exploratory Factor Analysis: The Influence of Sample Size, Communality, and Overdetermination, Educational and Psychological Measurement, 65(2): 202-226.

Hogg, M. A., Abrams, D. and Brewer, M. B. (2017). Social identity: The Role of Self in Group Processes and Intergroup Relations, Group Processes \& Intergroup Relations, 20(5): 570-581.

Hogg, M. A., Abrams, D., Otten, S. and Hinkle, S. (2004). The Social Identity Perspective: Intergroup Relations, Self-Conception, and Small Groups, Small Group Research, 35(3): 246-276.

Hogg, M. A. and Abrams, D. (1998). Social Identifications: A Social Psychology of Intergroup Relations and Group Processes, London and New York: Routledge.

Hogg, M. A. and Vaughan, G. M. (2007). Sosyal Psikoloji. (1.Basım). (Çeviren, Gelmez, A. ve Yıldız, İ.) İstanbul: Ütopya Yayınevi.

Hogg, M. A. and Williams, K. D. (2000). From I to We: Social Identity and the Collective Self, Group dynamics: Theory, Research, and Practice, 4(1): 81-97.

Horn, J. L. 1965. A Rationale and Test for the Number of Factors in Factor Analysis, Psychometrica, 30(2): 179-185.

Hoyle, R. H. and Crawford, A. M. (1994). Use of Individual-Level Data to Investigate Group Phenomena Issues and Strategies, Small Group Research, 25(4): 464-485

Jetten, J., Haslam, C., Haslam, S. A., Dingle, G. and Jones, J. M. (2014). How Groups Affect Our Health and Well-Being: The Path from Theory to Policy, Social Issues and Policy Review, 8(1): 103130.

Jetten, J., O'Brien, A. and Trindall, N. (2002). Changing Identity: Predicting Adjustment to Organizational Restructure as a Function of Subgroup and Superordinate Identification, British Journal of Social Psychology, 41(2): 281-297.

Jones, I. (2000). A Model of Serious Leisure Identification: The Case of Football Fandom, Leisure Studies, 19(4): 283-298.

Kaiser, H. F. (1974). An Index of Factorial Simplicity, Psychometrika, 39(1): 31-36.

Karaman, H., Atar, B. ve Çobanoğlu-Aktan, D. (2017). Açımlayıcı Faktör Analizinde Kullanılan Faktör Çıkartma Yöntemlerinin Karşılaştııılması, GEFAD, 37(3): 1173-1193.

Karasawa, M. (1991). Toward an Assessment of Social Identity: The Structure of Group Identification and Its Effects on In-Group Evaluations, British Journal of Social Psychology, 30(4): 293-307.

Küçük, S., Yılmaz, R. M., Baydaş, Ö. ve Göktaş, Y. (2014). Okullarda Artırılmış Gerçeklik Uygulamaları Tutum Ölçeği: Geçerlik ve Güvenirlik Çalışması, Eğitim ve Bilim, 39(2014): 383-392.

Kümbetoğlu, B. (2015). Sosyolojide ve Antropolojide Niteliksel Yöntem ve Araştırma. (4. Basım), Ankara: Bağlam Yayıncılık.

Lincoln, Y. S. and Guba, E. G. (1985). Naturalistic Inquiry, Thousand Oaks, CA: Sage.

Longhurst R. (2010). Semi- Structured Interviews and Focus Groups, (Editörler) Clifford, N., French, S. and Valentine, G.: Key Methods in Geography (2. Basım) içinde (ss. 103-115) London: Sage.

MacCallum, R. C., Widaman, K. F., Zhang, S. and Hong, S. (1999). Sample Size in Factor Analysis, Psychological Methods, 4(1): 84-99. 
Malhotra, N. K. (2006). Questionnaire Design and Scale Development, (Editörler) Grover, R. and Vriens, M.: The Handbook of Marketing Research: Uses, Misuses, and Future Advances içinde (ss. 176202) USA: Sage Publication.

Mvududu, N. H. and Sink, C. A. (2013). Factor Analysis in Counseling Research and Practice, Counseling Outcome Research and Evaluation, 4(2): 75-98.

Norman, G. R. and Streiner, D. L. (1998). Biostatistics - The Bare Essentials, Hamilton: B.C. Decker Inc.

Patton, M. Q. (2018). Nitel Araştırma ve Değerlendirme Yöntemleri (2. Basım). (3. Basımdan Çeviri) (Çeviren: Bütün, M ve Demir, S. B.) Ankara: Pegem Akademi.

Packer, D. J. (2008). On Being Both with Us and Against Us: A Normative Conflict Model of Dissent in Social Groups, Personality and Social Psychology Review, 12(1): 50-72.

Punch, K. F. (2016). Sosyal Araştırmalara Giriş Nicel ve Nitel Yaklaşımlar (4. Basım). (2. Basımdan Çeviri) (Çeviren: Bayrak, D., Arslan, H. B. ve Akyüz, Z.) Ankara: Siyasal Kitabevi.

Reicher, S., Spears, R. and Haslam, S. A. (2010). The Social Identity Approach in Social Psychology, (Editörler) Wetherell, M. and Mohanty, C. T.: The SAGE Handbook of Identities içinde (ss. 45-62) London: Sage Publications.

Shenton A. K. (2004). Strategies for Ensuring Trustworthiness in Qualitative Research Projects, Education for Information, 22(2): 63-75.

Sherif, M. (1967). Group Conflict and Co-Operation: Their Social Psychology, London: Psychology Press.

Swann, W. B., Jetten, J., Gómez, Á., Whitehouse, H. and Bastian, B. (2012). When Group Membership Gets Personal: A Theory of Identity Fusion, Psychological Review, 119(3): 441-456.

Swann, W. B. and Bosson, J. K. (2010). Self and Identity, (Editörler) Fiske, S. T., Gilbert, D. T. and Lindzey, G.: Handbook of Social Psychology (5. Edition) içinde (ss. 589-628) New Jersey: John Wiley \& Sons.

Tabachnick, B. G. and Fidell, L. S. (2015). Çok Değişkenli İstatistiklerin Kullanımı. (6. Basımdan çeviri) (Çevirmen: Baloğlu, M.) Ankara: Nobel Yayıncılık.

Tajfel, H. (1978). Differentiation Between Social Groups: Studies in the Social Psychology of Inter-Group Relations, London: Academic Press.

Tajfel, H. (1981). Human Groups and Social Categories: Studies in Social Psychology, New York: Cambridge University Press.

Tajfel, H. (1982). Social Psychology of Intergroup Relations, Annual Review of Psychology, 33(1): 139.

Tajfel, H. and Turner, J. C. (1979). An Integrative Theory of Intergroup Conflict, (Editörler) Austin, W. G. and Worchel, S.: The Social psychology of intergroup relations içinde (ss. 33-47) Monterey: Brooks/Cole.

Tinsley, H. E. and Tinsley, D. J. (1987). Uses of Factor Analysis in Counseling Psychology Research, Journal of Counseling Psychology, 34(4): 414-424.

Trepte, S. and Loy, L. S. (2017). Social Identity Theory and Self-Categorization Theory, (Editör) Rössler, P.: The International Encyclopedia of Media Effects içinde (ss. 1-13) London: John Wiley \& Sons, Inc. 
Turner, J. C. (1982). Towards a Cognitive Redefinition of the Social Group, (Editör) Tajfel, H.: Social Identity and Intergroup Relations içinde (ss. 15-40). New York: Cambridge University Press.

Turner, J. C., Oakes, P. J., Haslam, S. A. and McGarty, C. (1994). Self and Collective: Cognition and Social Context, Personality and Social Psychology Bulletin, 20(5): 454-463.

Turner, J. C., Reynolds, K. J., Haslam, S. A. and Veenstra, K. E. (2006). Reconceptualizing Personality: Producing Individuality by Defining the Personal Self, (Editörler) Postmes, T. and Jetten, J.: Individuality and the Group Advances in Social Identity içinde (ss. 11-36) London: Sage Publications.

Van Knippenberg, D., Van Knippenberg, B., Monden, L. and De Lima, F. (2002). Organizational Identification After a Merger: A Social Identity Perspective, British Journal of Social Psychology, 41(2): 233-252.

Velicer, W.F. (1976). Determining the Number of Components from the Matrix of Partial Correlations, Psychometrika, 41(3): 321-327.

Velicer, W. F. and Fava, J. L. (1998). Affects of Variable and Subject Sampling on Factor Pattern Recovery, Psychological Methods, 3(2): 231-251.

Veno, A. (2009). The Brotherhoods Inside the Outlaw Motorcycle Clubs. (3. Edition), Australia: Allen\&Unwin. 